$\rightarrow$ DOI : $10.15740 / \mathrm{HAS} / \mathrm{AJBS} / 11.2 / 321-325$

e ISSN-0976-8343 | 口isit us : www.researchjournal.co.in
ASIAN JOURNAL OF BIO SCIENCE

Volume 11 | Issue 2 | October, 2016 | 321-325

A REVIEW

\title{
Pulses: In need of more attention
}

\section{ROSHNI VIJAYAN}

Center for Plant Breeding and Genetics, Tamil Nadu Agricultural University, COIMBATORE (T. N.) INDIA

Email : roshnivij@gmail.com

Article Info : Received : 02.08.2016; Accepted : 24.09.2016

Pulses are an integral part of many diets across the globe. Pulses have great potential to improve human health, conserve our soils, protect the environment and contribute to global food security. The diversified agro-climatic condition in India positively supports variety of pulses in various regions. Pulses are grown in on area of 22-23 million hectares which has an annual production of 13-18 million tonnes. There is always a gap between actual yield and potential yield. This gap bridging would substantially increase country's pulses production. The potential areas of pulses may be identified and if provided with technological support then the area under pulses will be showing an upward trend.The total pulses production in the country is almost static although substantial productivity improvement in many of the pulse crops has been made. The static production of pulses is mainly due to poor adoption of improved varieties and production technologies by farmers. Even though pulses have high export value, we are importing pulses in order to meet the internal demands, as India is the largest producer as well as consumer of pulses. The instability in production has to be improved upon to meet the growing demands by using the emerging technologies.

Key words : Demand, Supply, Growth, Productivity, Pulses scenario, Yield gap

How to cite this paper: Vijayan, Roshni (2016). Pulses : In need of more attention. Asian J. Bio. Sci., 11 (2) : 321-325.DOI : 10.15740/HAS/ AJBS/11.2/321-325. 